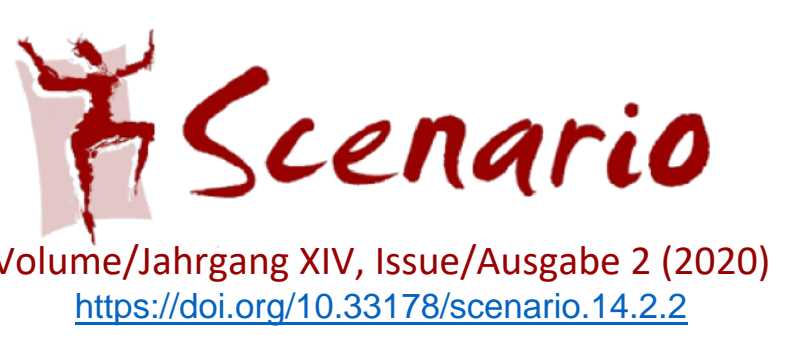

\title{
Drama-in-Education for Critical Historical Thinkers: A Case Study in the Greek Context
}

\author{
Katerina Kosti, Theodora Papaioannou
}

The case study presented in this article refers to the connection of drama-in-education and critical thinking in history, in order to highlight the importance of drama for the teaching of history in primary schools in Greece. The research plan adopted is quantitative and qualitative, and the research strategy applied is that of case study. For the purposes of this study, four scenarios based on drama-in-education techniques were designed and applied on a sample of forty-three primary students. The analysis of the findings show that the students' understanding of historical contexts and objectives of historically active subjects was encouraged by drama-based instruction.

\section{Introduction}

In recent decades, there has been a growing trend among teachers, educators, and historians in teaching and producing new teaching materials, with an emphasis on content selection, interdisciplinary approaches, and active forms of teaching (Levstik \& Barton 2011). These views treat the student as an active recipient and bearer of historical thought and are based on constructivist learning theories, with the aim to emphasize the relationship between the learning of historical events and the construction of metacognitive skills for cultivating students' critical thinking (Kosti 2016, Saye \& Brush 2002: 78, Davis 2001: 6, Foster 2001: 171 and 175-176).

The intention to revise history teaching methods is time-consuming; visits to libraries and archives, museums and archeological sites, use of oral testimonies, historical novels and cinema in the classroom, Information and Communications Technology and the Internet are some of the new learning environments proposed for the development of students' historical thinking (Levstik \& Barton 2011). Activities as well as role playing, simulations, etc. are also suggested for delving into the meaning of historical terms and concepts such as historical time, historical interpretation and rational thinking in history (Shemilt 1984: 66-78). 


\section{Drama in Education and Historical Critical Thinking}

In the context of critical historical thought, a special role could be played by Drama in Education, an exploratory and experimental approach to learning which includes interaction of thinking and knowledge, aesthetic and kinesthetic experiences, decision making, and understanding of multiple historical events (Kosti 2016, Booth 2012, Rantala 2011, O' Toole et al. 2009: 185, Heathcote 2008). It is a teaching approach that is based on imaginary "as-if" worlds and promotes learning through improvisation; it is closely linked to the curriculum of History (O 'Toole et al. 2009: 107-108).

In this teaching context, students as active learners structure their knowledge based on their experiences (O'Toole et al. 2009: 105, Wagner 1985: 166). Students have the opportunity to develop abstract thinking, to use their imagination and body through role creating, and to experience creative expression of feelings and ideas. Key elements of learning in Drama in Education contexts are mutual agreement between teacher and students, creative pretense and pleasure of learning (Kosti 2016, Kondoyianni 2012, O'Toole et al. 2009: 11, Fairclough 1994, Fleming 1992).

The cooperative procedures of learning and the teacher's role of a cognitive guide or facilitator are key elements of Drama in the classroom; that is why the link between Drama and Historical Empathy seems to be very strong, such as Fines and Verrier (1974) pointed out and drama teachers have persistently reported (Kempe 2013 and 2011). Fines and Verrier (1974: 83-89) argue that there is a close relationship between History and Drama, with specific results in making historical meaning by using respective sources of the past.

The use of Drama in Education as a teaching approach to critical historical thought has been embraced by historians themselves; Thompson (1983: 21-13) argues that the development of this skill can be achieved through Drama and role play, while Little (1983: 12-16) considers Drama in history classroom to be invaluable, as it convinces students of the reality of the past and offers them opportunities to reflect on it through guided use of their imagination and sessions of action and discussion. Moving along the same lines, Goalen and Hendy (1993; 1992, Goalen 1995) have experimentally proven that the historical thinking of averageperformance students develops when they approach the historical material through dramain-education techniques.

Drama activates the symbolic thinking of students, resulting in the formation of new meanings and the development of a holistic learning concerning declarative knowledge, as well as creative imagination, social skills and self-confidence, which are focal points for the construction of critical thinking (O'Toole et al. 2009: 81-89). All of these forms of learning are 
related to the concept of historical critical thinking or, as many theorists of history call it, historical empathy (Kosti 2016, Kosti et al. 2015, Nichol 2013, Dodwell 2013, Kondoyanni \& Kosti 2011, Levstik \& Barton 2011, Kempe 2011, Williams 2009, Belliveau et al. 2008).

The concept of historical empathy as an element of historical thought has exerted an important influence on the theory and teaching of history in school, which aims at understanding and interpretation of historical reality. And despite some existing opinions that empathy is hard to achieve in the context of the classroom, research has shown that students can indeed achieve satisfactory levels of empathy if provided with a wide range of activities (Kosti et al. 2015).

In fact, Lee, Dickinson and Ashby (Lee et al. 1997; see also Ashby and Lee 1987, Lee and Ashby 2001;) have developed a descriptive system that encompasses the stages of empathy primary and secondary education students go through; the present analysis will be based on these five stages, because this system has been most noted and widely used (Kosti et al. 2015, Barton \& Levstik 2008: 277):

- "The Divi Past". At this initial stage, students see the past as incomprehensible and essentially view people from the past as 'stupid' or 'thick' because they did things much differently from people in nowadays.

- "Generalized Stereotypes". Here past actions are evaluated generically in terms of conventional stereotyped roles.

- "Everyday Empathy". Past actions are set against the cultural contexts of today's world, without consistently distinguishing between the older and the modern views and values.

- "Restricted Historical Empathy". The recognition is established that people in the past had a different level of knowledge than ours, different views and values, but no depth is reached in their representation and interpretation.

- "Contextual Historical Empathy". Past actions are eventually viewed as integrated in a wider context of views and values, and it is recognized that they form a network of goals reaching far beyond any appearances.

Drama in Education as a student-centered pedagogical approach seems to have a lot to offer in teaching history. In this context, the present study proposes a framework of history didactics which is based on the principles of drama in education and focused on critical historical thinking. The framework in question focuses on students of the primary level of education, where there has been no extended research, and students of the 5th grade, providing a fertile ground for research experimentations. 


\section{Research Restrictions, Aim and Method}

A mixed approach, of quantitative and qualitative orientation, according to the principles of case study (Charmaz 1995, Greene 2007. Cohen 2011) was considered the most appropriate method for this research.

The research questions were:

- Can critical historical thinking of primary school pupils be impacted by drama?

- If so, how can drama enhance the historical thinking of primary school pupils?

The qualitative approach responded to both of the research questions raised above, while the quantitative approach complemented and reinforced the qualitative in relation to the first question.

Four interventions with a group of pupils of the 5th grade of Primary School were conducted to collect qualitative and quantitative data. The interventions were implemented over a period of three months (February - April 2019). Each intervention lasted 40 minutes and took place in the History classroom. The educational program in the context of which this research was implemented was included in the curriculum and approved by the Primary Education Office of Larissa. The pupils were asked to fill in two questionnaires, one before and one after the interventions. Hence, the research design was one-group pretest-posttest quasiexperimental.

In this particular research project teacher and researcher functions overlapped. This means that the teacher took on different roles, such as the role of facilitator, supporter and mentor. Collecting her own data as researcher helped speed up the process of assimilation in the classroom environment and allowed her to make better and quicker decisions (Mertler 2012: 27).

The sample members were forty-three (43), twenty-five (25) boys and eighteen (19) girls. The whole research design was approved by the Primary Education Directorate of Larissa and students' parents were informed by a consent letter which included a description of the research topic, a description of what participation would involve, an indication that the participation was voluntary, a guarantee of anonymity and an offer to provide a summary of the findings to participants; all the parents gave their informed consent by signing the form (see also Mertler 2012: 102-104).

Since the research was exclusively conducted in only one primary school in Larissa, the capital of the Thessaly region in Greece, it is restricted, without claims to generalization. Its significance lies in the fact that it attempts to investigate the relationship between drama and 
history in the Greek context, highlighting possible influences of drama in the critical historical thinking of primary school pupils, specifically while monitoring and describing the process of formulating causal relationships.

\section{Quantitative Analysis}

For the purpose of the research a questionnaire was composed to measure critical historical thinking of the sample pupils. The questionnaire consisted of four open-ended questions related to historical sources and investigated if students understood why things happened in history (Dickinson \& Lee 1978). The first question simply asked what Constantine was seeking by the construction of Constantinople. The second question allowed subjects to show how far their first answer really represented their understanding; for this purpose students were asked why Justinian undertook such a large building project throughout the empire and especially the Hagia Sophia in Constantinople. The third question pressed harder by asking how it was possible to explain the fact that while the goal of the Crusaders was the liberation of the Holy Land from the pagans, the Fourth Crusade ended in the occupation and looting of Constantinople, a city with a Christian population. The fourth question was indended to overcome the limitations of the other questions by asking of the reasons that led to the Fall of Constantinople.

The category system used to evaluate the responses was that of the above-mentioned five stages of historical empathy. Each stage was graded with the corresponding grade. Some sample answers are cited below:

- Stage 1 - Grade 1 (The Divi Past): “Crusaders were bad people; they only knew how to kill". Answer to question 3 - Student with lower academic profile (pre-test).

- Stage 2 - Grade 2 (Generalized Stereotypes): “Hagia Sophia in Constantinople was built to be a miracle". Answer to question 2 - Student with upper academic profile (pretest).

- Stage 3 - Grade 3 (Everyday Empathy): "Everyone would like to conquer Istanbul, because people love money and grandeur -and Constantinople was the richest city of its time. Whoever owned that city was the ruler of the world". Answer to question $3-$ Student with middle academic profile (post-test).

- Stage 4 - Grade 4 (Restricted Historical Empathy): "Nothing remains the same in history. Everything has its ups and downs. This was done with Istanbul". Anwer to question 4 - Student with upper academic profile (post-test).

- Stage 5 - Grade 5 (Contextual Historical Empathy): No answer was given. 
The questionnaire was piloted and tested for its validity using the Cronbach alpha statistical criterion, with acceptable values (see Table 1) and was given to the sample pupils before and after the experimental manipulation.

\begin{tabular}{|l|l|l|}
\hline & Pre-test & Post-test \\
\hline Cronbach's Alpha & 0,688 & 0,778 \\
\hline N of Items & 4 & 4 \\
\hline
\end{tabular}

Table 1: Cronbach's alpha

Data were processed by using SPSS v.20 and the procedure followed the principles of descriptive and inferential statistics. At the same time, the randomness of the sample was checked and confirmed, while the normality was checked but not confirmed by Shapiro-Wilk test. This was the reason for using nonparametric Wilcoxon Signed Ranks Test for related samples and Man-Whitney $U$ Test for independent samples for the conclusions according to the principles of inductive statistics.

The effect of drama was clear on the variable of "Historical thinking", as the sample pupils showed statistically significant improvements after the manipulation compared to the beginning (see Table 2).

\begin{tabular}{|l|ll|l|}
\hline Variables & Means & \multicolumn{2}{|c|}{ Wilcoxon Signed Ranks Test } \\
\hline & & Z & Asymp. Sig. (2-tailed) \\
\hline Historical thinking - pre & 0,7791 & $-5,525$ &, $000(<0,001)$ \\
\hline Historical thinking - post & 2,2965 & & \\
\hline
\end{tabular}

Table 2: Wilcoxon Signed Ranks Test values during pre-test and post-test

Looking more closely at the broad bands of pupils' ability (as defined by school grades), statistically significant improvements were shown in all academic performances, lower, middle and upper (see Table 3).

\begin{tabular}{|l|l|l|l|l|}
\hline Variables & \multicolumn{2}{l|}{ Means } & Wilcoxon Signed Ranks Test \\
\hline & pre & post & Z & Asymp. Sig. (2-tailed) \\
\hline Lower (11 pupils) & 0,4318 & 1,6136 & $-2,675$ & $0,007(<0,01)$ \\
\hline Middle (21 pupils) & 0,7857 & 2,2965 & $-3,930$ & $0,000(<0,001)$ \\
Upper (11 pupils) & 1,1136 & 2,9545 & $-2,943$ & $0,003(<0,01)$ \\
\hline
\end{tabular}

Table 3: Wilcoxon Signed Ranks Test values during pre-test and post-test in lower, middle and upper academic performance 


\section{Description of interventions}

Interventions that took place in the framework of the educational program, as mentioned, concerned the teaching of didactic units of the History Curriculum of $5^{\text {th }}$ grade of Primary School through techniques of Drama in Education (DiE). According to the Curriculum of History (Ministry of Education 2018) of this class, Drama in Education techniques will be used to facilitate the understanding of historical events of the Byzantine period.

The first didactic intervention about the founding of Constantinople started off with the technique "Teacher in Role" (Heathcote 1985) of historian-narrator in combination with the technique of "Role Play" (Avdi \& Hatzigeorgiou 2018: 52) during which the students watched the narration of the teacher impersonating citizens of the Byzantine period who lived in Rome. After the narration, the students created a "Still-Image" that concerned the roles ofcitizens they had taken on without movement and speech (Avdi \& Hatzigeorgiou 2007: 86; Papadopoulos 2010: 247). Then a student sat on the "throne" of Constantine the Great and read from a piece of paper in the form of parchment concerning the transfer of the capital to Byzantium. The search for the reasons why it was considered necessary to move the capital was carried out through the "Hot-Seating" activity (Alkistis 2008: 264; Avdi \& Hatzigeorgiou 2007: 91) and the activity "Voices in the head" (Neelands \& Goode 2011: 92) demonstrated the students' views on the decision that Konstantinos had to make. At the end of the intervention, an evaluation and reflection were carried out through the "Writing in Role" technique (Alkistis 2008: 380 and 388, Avdi \& Hatzigeorgiou 2007: 96, Papadopoulos 2010: 257). The students wrote in their diary, taking on the role of Constantine writing down his thoughts about the founding of Constantinople shortly before his death.

The second intervention revolved around the Church of Hagia Sophia (Holy Wisdom Church)., The technique "Time Machine" (Alkistis 2008: 267) was used to create the appropriate spacetime frame (Constantinople, 532 AD, after the "Nika" revolution). The dramatic environment was created through a dramatized narration by the teacher about the events of the specific period. After that a student in the role of emperor Justinian expressed his concerns about dealing with the disasters caused in the Church of Hagia Sophia. The other students in the roles of political advisors, architects and priests, created groups and through the technique "Mantle of the expert" (Heathcote \& Bolton, 1995) proposed solutions to Justinian. Then the teacher took the role of the "ghost" of Constantine the Great which appeared to Justinian in his sleep and advised him what he must do to become a great emperor and remain famous in the following centuries. The intervention was completed with the "Writing in Role" technique: students in the role of residents of the Constantinople, 6 years after the events, stood in front of the majestic church of Hagia Sophia and wrote a message or a comment to Justinian and left it outside the temple. 
The topic of the third intervention was the Fall of Constantinople. The students in the role of the crusaders walked to Venice and prepared themselves for the fourth crusade to gain the spoils and wealth they had been promised. The development of the drama took place through the following techniques: "Teacher in role" in which the teacher as Angelos Alexios spoke to the crusaders (students) about his desire to occupy the city to regain his throne and the spoils and the wealth that he would offer them in case they helped him regain power. Other techniques were "Team Dialogue" (Alkistis 2008: 262), featuring the meeting of the crusaders to arrive at a relevant decision and "Consciousness Alley" (Avdi \& Hatzigeorgiou 2007: 92), during which a student in the role of admiral of the crusaders went through the corridor of consciousness and made the final decision: "Let's conquer the Constantinople". The evaluation was carried out through the "Writing in Role" in which the students in the role of crusaders after the Fall reconsidered the destruction, looting and massacres they committed and wrote in their diary a note whether their decision was correct or not.

As to the fourth intervention, The Fall of Constantinople by the Ottoman Turks, a movement activity was initially carried out with the free walking of the students in the role of Serbs in the appropriately designed classroom area. During the activity, the teacher in the role of "messenger" announced to the Serbs (students) the news of the Fall of the Constantinople so that they could think and express their views on the event. The students then took on the roles of neighboring peoples of the Byzantine Empire, formed the respective groups and presented, through the technique "Still-Image", the impact of the Fall of the Constantinople on other peoples, giving a title to the "image" they created. Finally, a reflection took place through the "Writing in Role" technique, as students as citizens of neighboring peoples wrote a verse about Constantinople.

\section{Qualitative analysis}

The findings of the quantitative analysis were further explored through the qualitative approach, in which the interventions performed in the sample group were analyzed. These interventions focused on the founding of Constantinople, the Church of Hagia Sophia (Holy Wisdom Church), the Fall of Constantinople and the Fall of Constantinople. Qualitative analysis was performed through thematic content analysis in order to analyze in detail the data that emerged from the interventions and to structure it in categories and thematic fields (Robson 2007: 416-418, Sarafidou 2011: 117).

The findings of the qualitative analysis are consistent with the results of the quantitative analysis, as the data analysis showed that the techniques of Drama in Education contributed to the participating pupils' critical historical thinking, understanding and empathy. 
In particular, in the first interventionabout the establishment of Constantinople, it turned out that the techniques of Drama aroused the interest of students and positively activated their involvement in the learning process. Based on the data, it emerged that the students were in the second stage of empathy ("Generalized Stereotypes"). Specifically, two categories of thematic analysis emerged from the analysis of the texts produced by the students in "Writing in role" technique (Alkistis 2008: 380 \& 388, Avdi \& Hatzigeorgiou 2007: 96, Papadopoulos 2010: 257); the first category demonstrated empathy and the second historical understanding. ${ }^{1}$

Regarding historical empathy, students critically acquired historical knowledge, as was shown in their written discourse of possible thoughts of historically active subjects (Constantine the Great):

- $\quad$ Student 1 (lower academic performance): "I feel very proud for what I did because it had perfect results. Christian faith spread widely and citizens of Constantinople liked it very much because they made it equal to Rome."

- $\quad$ Student 2 (middle academic performance): "I feel that the work I have done is very important and I am very pleased that I have fortified the new capital, Constantinople, with big walls and made it safer from enemies."

- $\quad$ Student 3 (middle academic performance): “Me, Constantine the Great, I am very happy for everything I have done; I built the Aqueduct and the Forum; I gave privileges and financial incentives to those who were concerned with the security of the city walls, because they helped my people."

- $\quad$ Student 4 (upper academic performance): "I am very proud of the decisions I made as a monarch, because of the difficulty of the governance; I also managed to resolve the theological differences by attaining consensus in the church through an assembly representing all of Christendom in Nicaea in 325 AD.

As for historical understanding, it was found that students understood the aims and objectives of historically active subjects (Constantine the Great) who acted in the Byzantine years and also understood that their actions were influenced by many factors and were the result of complex processes:

- $\quad$ Student 5 (middle academic performance): "I moved the capital from Rome to Byzantium because Rome was very far from outermost areas; it was for many years the worship center of "Roman pantheon", a place where conflicts took place between hierarchs and persecutions of Christians occurred."

\footnotetext{
${ }^{1}$ It should be noted that the following data are just a few selected examples, only a fraction of the total findings collected.
} 
- $\quad$ Student 6 (middle academic performance): "I made all my decisions so that the people of Istanbul could live in the most beautiful city; I also applied what I mentioned in the Edict of Milan and so I supported the persecuted Christian religion."

- $\quad$ Student 7 (lower academic performance): "I decided to move to the capital because there were so many problems and my people and I could not live comfortably and peacefully; and it was difficult to rule the empire from Rome."

- Student 8 (lower academic performance): "I built Constantinople, the most beautiful city, so that many foreigners visit it and admire it; I also built Christian temples to help spread the Christian religion."

Relevant results emerged from the subsequent interventions, as the analysis of the data revealed the aforementioned themes of thematic analysis. In the second intervention on the Church of Hagia Sophia (Holy Wisdom Church), analysis of the data highlighted the development of historical understanding and it emerged that the students were in the second stage of empathy ("Generalized Stereotypes"). Particularly, students expressed positive feelings about the creation of Hagia Sophia; at the same time, they structured their historical knowledge creatively and critically:

- $\quad$ Student 9 (lower academic performance): “Emperor Justinian, I want to tell you that Hagia Sophia is the best in the world and the most beautiful. You have created a wonderful temple. Well done!"

- $\quad$ Student 10 (middle academic performance): “Emperor Justinian, I would like to thank you very much for this wonderful and luxurious temple, the Hagia Sophia, which will go down in history forever."

- $\quad$ Student 11 (lower academic performance): “Emperor Justinian, you are doing a great job. You have created a great and amazing temple that all the inhabitants of the city admire. Congratulations!"

- $\quad$ Student 12 (upper academic performance): “Justinian, the best emperor! Hagia Sophia is a unique church in the entire world. Well done to the architects Anthemios and Isidoros and to the citizens, who offered materials and money for the construction."

- $\quad$ Student 13 (lower academic performance): “Congratulations for the magnificent masterpiece! The architecture and decoration of the temple is dazzling. Well done for the great idea".

- $\quad$ Student 14 (middle academic performance): "The best temple in the world, Hagia Sophia, a Domed-Basilica. It is built in such a way that it will last for many centuries, it will be a symbol of Christianity and many people will admire it". 
The third intervention dealt with the Fall of Constantinople. Based on the data, it emerged that the students were in the third stage of empathy ("Everyday Empathy"). Specifically, analysis of the documents produced by the students showed that historical empathy was achieved, as they recorded their views and feelings as crusaders after the fall of the city and it seemed that they understood the aims of the historically active subjects and of their actions:

- $\quad$ Student 15 (middle academic performance): “My dear diary, our decision to invade the city was not right. We wanted glory and money, but many human lives were lost and, worst of all, we plundered Hagia Sophia."

- $\quad$ Student 16 (upper academic performance): “My dear diary, I realized that the decision I had made was not the right one. But I did it for the money and gifts that Alexios Angelos would give us; but the only thing he wanted was to take the throne again. We did not even respect churches and sacred icons and holy vessels."

- $\quad$ Student 17 (middle academic performance): “My favorite diary, I made a wrong decision. I shouldn't have gone with Alexios. I shouldn't have looted the Hagia Sophia. I was distracted by the opinion of the other crusaders."

- $\quad$ Student 18 (lower academic performance): “Our decision was not right. We made a big mistake. We should be ashamed of ourselves."

- $\quad$ Student 19 (middle academic performance): "I am a crusader; the decision we took to invade Constantinople and to kill so many people was wrong; I felt very bad, I felt awful for it. If I could, I would go back in time to change it."

- Student 20 (lower academic performance): "The decision I made was wrong; I destroyed Hagia Sophia; a lot of people were killed and the Byzantine Empire was destroyed."

Based on the results of the fourth intervention, which dealt with the Fall of Constantinople, it was found that historical understanding was strengthened and it emerged that the students were in the third stage of empathy ("Everyday Empathy"). The analysis of the documents produced by the students in the form of creative writing showed that historical context which was taught through the techniques of drama was satisfactorily understood; students were capable of using pre-existing historical knowledge acquired in previous educational interventions critically:

- $\quad$ Student 21 (middle academic performance):

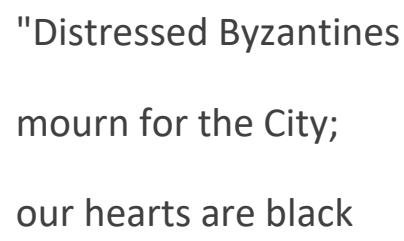


Kosti, Papaioannou: Drama-in-education for critical historical thinkers

our whole life is gone."

- $\quad$ Student 22 (lower academic performance):

"Fear, pain, sorrow fell on the queen city.

I'm scared, I'm crying, I'm leaving, I cannot stand it.

Constantinople fell. "

- $\quad$ Student 23 (middle academic performance):

"It was Tuesday, May 29, 1453, a sad day.

Our city fell into foreign hands, into a foreign embrace."

- $\quad$ Student 24 (upper academic performance):

"Oh! My city, my beloved Queen!!!

You fought hard,

but slavery came from the back door.

Tuesday, May 29, 1453 - day of evil."

- $\quad$ Student 25 (lower academic performance):

"The Queen City is lost and does not return and if she returns she will not be like before."

- $\quad$ Student 26 (upper academic performance):

"Tuesday, May 29, 1453 / A city is lost forever and will never return. / I felt sad because they so many thousands of people were lost. The Queen City is lost FOREVER !!!"

\section{Concluding note}

The aim of this article is to argue that drama-in-education can present an effective approach of enhancing the historical thinking for primary school students in the Greek context. For this purpose, a mixed-method quantitative and qualitative research approach was used according to the principles of case study. As previously reported, the findings presented here are limited, as the study is a small-scale research in only one school. Hence the conclusions listed below can be seen as merely indicative and cannot be generalized.

As quantitative and qualitative analyses have highlighted, students demonstrated a development in their critical thinking towards the past. The Drama in Education approach 
facilitated this achievement, since it offered a learner-centered environment in which all students, regardless of their individual academic performance, were able to develop critical historical thinking and they felt free to express their opinions without the fear of being inaccurate in their analyses of the past. And this because drama has a potentional of awaking the students to the real dimension of the past.

Perhaps the most important conclusion drawn from these four instructional interventions is that the students embraced Drama with enthusiasm, and responded satisfactorily to the challenges they were presented with. These findings could be regarded as a very important starting point for educational research in Greece, on the purpose of possible proposals for inclusion of Drama-in-Education techniques in the reshaping of primary school history curriculum.

\section{Bibliography}

Alkistis (2008): Mavri Agelada- Aspri Agelada. Dramatiki Tehni stin Ekpaideusi kai Diapolitismikotita.

Athens: Topos. [Alkistis (2008): Black Cow - White Cow. Drama-in-education and Interculturalism. Athens: Topos]

Ashby, Rosalyn \& Lee, Peter (1987). Children's Concepts of Empathy and Understanding in History. In: Portal, Christopher (ed.): The History Curriculum for Teachers. London: Falmer, 62-88

Avdi, Avra \& Chatzigeorgiou, Melina (2007): Techni tou Dramatos stin Ekpaideusi. Athens:

Metaihmio. [Avdi, Avra \& Chatzigeorgiou, Melina (2007): The Art of Drama-in-education. Athens: Metaihmio]

Avdi, Avra \& Chatzigeorgiou, Melina (2018): Otan o daskalos mpeni se rolo. Athens: Metaihmio.

[Avdi, Avra \& Chatzigeorgiou, Melina (2018): When the teacher gets in role. Athens: Metaihmio]

Barton, Keith \& Levstik, Linda (2008): Didaskontas Istoria gia to Syllogiko Agatho (transl. in Greek: Theodorakakou Afrodite). Athens: Metaihmio. [Barton, Keith and Levstik, Linda (2004): Teaching History for the Common Good. Mahwah, New Jersey: Lawrence Erlbaum Associates, Inc., https://doi.org/10.4324/9781410610508]

Belliveau, George; Prendergast, Monika \& Anderson, Hugh (2008): BC History in Action. A Guide to Teaching History Through Drama. Grades 8 to 12. London: British Columbia Ministry of Education. http://www2.gov.bc.ca reducation steachıpdfs >drama812 [last assessed April 22, 2020]

Booth, David (2012): Reconsidering Dorothy Heathcote's Educational Legacy. In: Drama Research 3/1, Testimony, 1-19. http://www.nationaldrama.org.uk/journal/wpcontent/uploads/sites/2/Testimony.pdf [last accessed April 22, 2020]

Charmaz, Kathy (1995): Grounded Theory. In: Smith, Jonathan A.; Harré, Rom \& Van Langenhove, Luk (eds.): Rethinking Methods in Psychology. Thousand Oaks: Sage, 27-49, https://doi.org/10.4135/9781446221792.n3 
Kosti, Papaioannou: Drama-in-education for critical historical thinkers

Cohen, Louis (2011): Research Methods in Education. London: Routledge

Davis, O.L. (2001): In Pursuit of Historical Empathy. In: Davis, O.L.; Yeager, Elizabeth Anne \& Foster, Stuart J. (eds.): Historical Empathy and Perspective Taking in the Social Studies. Lanham: Rowman \& Littlefield, Publishers, INC., 1-12

Dickinson, Alaric \& Lee, Peter (1978): Understanding and Research. In: Dickinson, Alaric \& Lee, Peter (eds.): History Teaching and Historical Understanding. London: Heinemann, 94-120

Dodwell, Cherry (2013): Using Creative Drama Approaches for the Teaching of History. In: Cooper, Hilary (ed.): Teaching History Creatively. Abingdon Oxon: Taylor \& Francis, 119-133

Fairclough, John (1994): History Through Role-Play. London: English Heritage

Fines, John, \& Verrier, Raymond (1974): The Drama of History. An Experiment in Co-operative Teaching. London: New University Education

Fleming, Kate (1992): A Land fit for Heroes: Recreating the Past through Drama. In: Teaching History $68,14-16$

Foster, Stuart J. (2001): Historical Empathy in Theory and Practice: Some Final Thoughts. In: Davis, O.L.; Yeager, Elizabeth Anne \& Foster, Stuart J. (eds.): Historical Empathy and Perspective Taking in the Social Studies. Lanham: Rowman \& Littlefield, Publishers, INC., 167-181

Goalen, Paul \& Hendy, Lesley (1992): The Challenge of Drama: An Historical Investigation of Sati. In: Teaching History 69, 26-33

Goalen, Paul \& Hendy, Lesley (1993): “It's not Just Fun, It Works!” Developing Children's Historical Thinking Through Drama. In: The Curriculum Journal 4/3, 363-384, https://doi.org/10.1080/0958517930040305

Goalen, Paul (1995): Twenty Years of History through Drama. In: The Curriculum Journal 6/1, 63-77, https://doi.org/10.1080/0958517950060105

Greene, Jennifer (2007): Mixed Methods in Social Inquiry. New York: Wiley

Heathcote, Dorothy (1985): Collected Writings on Education and Drama. London: Hutchinson

Heathcote, Dorothy \& Bolton, Gavin (1995): Drama for Learning: Dorothy Heathcote's Mantle of the Expert Approach to Education. Portsmouth: Heinemann Press

Heathcote, Dorothy (2008): Means and Ends: History, Drama and Education for Life. In: Primary History 48, 6-7

Kempe, Andy (2012): "Superteachers", Saints and Solitaires: An Investigation into Advanced Skills Teachers of Drama. In: Drama Research 3/1, 1-20. http://www.nationaldrama.org.uk/journal/wpcontent/uploads/sites/2/Andy-Kempe.pdf [last accessed April 22, 2020]

Kempe, Andy (2011): Daisy's Diary: Issues Surrounding Teaching History through Drama. In: Drama Research 2/1, 1-16. http://www.nationaldrama.org.uk/wp-content/uploads/sites/2/DR-Vol2-No1Article-2-Daisy-s-diary.pdf [last accessed April 22, 2020]

Kondoyianni, Alkistis \& Kosti, Katerina (2011): Eğitimde Drama Yolu ile Tarihsel Empatiyi Beslemek: Lise Birinci Sınıf Öğrencileriyle Gerçekleştirilen Bir Eylem Araştirmasi. In: Yaratici Drama Dergisi 
6/12, 52-57. http://www.yader.org/index.php/yader/article/view/yader.2011.009 [last assessed April 22, 2020]

Kontoyianni, Alkistis (2012): Dramatiki Techni stin Ekpaideusi. Athens: Pedio. [Kontogianni, Alkistis (2011): Drama-in-education. Athens: Pedio]

Kosti, Katerina (2016): Drama in education as a mean for fostering historical empathy in high school student. Unpublished PhD Dissertation. Nafplion: University of Peloponesse

Kosti, Katerina; Kondoyianni, Alkistis \& Tsiaras, Asterios (2015): Fostering Historical Empathy through Drama-in-Education: A Pilot Study on Secondary School Students in Greece. In: Drama Research 6/1, 1-23. http://www.nationaldrama.org.uk/journal/wpcontent/uploads/sites/2/Katerina_Kosti_et_al.pdf [last accessed April 22, 2020]

Lee, Peter \& Ashby, Rosalyn (2001): Empathy, Perspective Taking, and Rational Understanding. In: Davis, O.L.; Yeager, Elizabeth Anne \& Foster, Stuart J. (eds.): Historical Empathy and Perspective Taking in the Social Studies. Lanham: Rowman \& Littlefield, Publishers, INC., 21-50

Lee, Peter; Dickinson, Alaric \& Ashby, Rosalyn (1997): "Just Another Emperor": Understanding Action in the Past. In: International Journal of Educational Research 27/3, 233-244, https://doi.org/10.1016/S0883-0355(97)89731-5

Levstik, Linda \& Barton, Keith (2011): Doing History. New York: Routledge, https://doi.org/10.4324/9780203834930

Little, Vivienne (1983): History through Drama with Top Juniors. In: Education 3-13 11/2, 12-18, https://doi.org/10.1080/03004278385200171

Mertler, Craig A. (2012): Action Research: Improving Schools and Empowering Educators. Thousand Oaks, CA: SAGE Publications, Inc.

Ministry of Education (2018): Programma Spoudon Istorias pemtis taxis (2018). Athens: Ministry of Education in Greece [Ministry of Education in Greece (2018): Curriculum for the teaching of History 5th grade. Athens: Ministry of Education in Greece]

Neelands, Jonathan \& Goode, Tony (2011): Structuring Drama Work. Cambridge: Cambridge University Press

Nichol, Jon (2013): Creativity and Historical Investigation: Pupils in Role as History Detectives (protohistorians) and as Historical Agents. In: Cooper, Hilary (ed.): Teaching History Creatively. Abingdon Oxon: Taylor \& Francis, 101-118

O' Toole, John; Stinson, Madonna \& Moore, Tiina (2009): Drama and Curriculum: A Giant at the Door. Sydney: Springer

Papadopoulos, Simos (2010): Paidagogiki tou Theatrou. Athens: Idiotiki ekdosi [Papadopoulos, Simos (2010): Theatre Pedagogy. Athens: Private edition]

Rantala, Jukka (2011): Assessing historical empathy through simulation - How do Finnish teacher students achieve contextual historical empathy? In: Nordidactica - Journal of Humanities and Social Science Education 1/1, 58-76 
Kosti, Papaioannou: Drama-in-education for critical historical thinkers

Robson, Colin (2010): Ereuna tou Pragmatikou Kosmou (transl. into Greek: Dalakou Katerina). Athens: Gutenberg. [Robson, Colin (1993): Real World Research. Oxford: Blackwell Publishing Ltd.]

Sarafidou Yasemi-Olga (2011): Synarthrosi Posotikon ke Poiotikon Prosegiseon. Athens: Gutenberg. [Sarafidou Yasemi-Olga (2011): Quantitative and Qualitative Approaches' Articulation. Athens: Gutenberg]

Saye, John \& Brush, Thomas (2002): Scaffolding Critical Reasoning about History and Social Issues in Multimedia-Supported Learning Environments. In: Educational Technology Research and Development 50/3, 77-96, https://doi.org/10.1007/BF02505026

Shemilt, Denis (1984): Beauty and the Philosopher: Empathy in History and Classroom. In: Dickinson, Alaric K.; Lee, Peter J. \& Rogers, Peter J. (eds.): Learning History. Oxford: Heinemann, 39-84

Thompson, Fred (1983): Empathy: an Aim and a Skill to be Developed. In: Teaching History 37, 22-26 Wagner, Betty Jane (1985): Elevating the Written Word through the Spoken: Dorothy Heathcote and a Group of 9- to 13-Year-Olds as Monks. In: Theory into Practice 24/3, 166-172, https://doi.org/10.1080/00405848509543168

Williams, Yohuru (2009): Teaching U.S. History Beyond the Textbook: Six Strategies for Grades 5-12. Thousand Oaks: Sage 